\title{
Administration of Vincristine in a Patient with Machado-Joseph Disease
}

\author{
Anna Colpo $^{a}$ Frederick H. Wilson $^{b}$ Valentina Nardi ${ }^{c}$ Ephraim Hochberg ${ }^{b}$ \\ a Department of Medicine, Haematology and Clinical Immunology, University of Padua School of Medicine, \\ Padua, Italy; ${ }^{b}$ Division of Haematology/Oncology, and ' Department of Pathology, Massachusetts General Hospital, \\ Boston, Mass., USA
}

\section{Key Words}

Machado-Joseph disease - Spinocerebellar ataxia type $3 \cdot$

Vinca alkaloid $\cdot$ Vincristine

\begin{abstract}
Chemotherapy-induced peripheral neurotoxicity is a major problem because it represents the dose-limiting side effect of a significant number of antineoplastic drugs, such as vinca alkaloids. Hereditary neuropathies usually predispose to severe vincristine neurotoxicity. Here, we report the case of a 56-year-old man with Machado-Joseph disease, also known as spinocerebellar ataxia type 3 , treated with a vinca alkaloid without exacerbation of neurological symptoms.
\end{abstract}

Copyright $\odot 2012$ S. Karger AG, Basel

In December 2010, a 56-year-old man with a 14-year history of Machado-Joseph disease (MJD) noted a nontender, painless mass in his right axilla. He denied any associated symptoms, in particular fever, night sweats or weight loss over the preceding 6 months. An ultrasound of the right axilla showed a $3.0 \times 3.3 \times 2.7-\mathrm{cm}$ lymph node along with several other enlarged nodes nearby. One month later, an excisional lymph node biopsy was consistent with diffuse large B-cell lymphoma, anaplastic variant.

He had a baseline Eastern Cooperative Oncology Group (ECOG) performance status of 2-3. His MJD symptoms included: clumsiness, bilateral sensory paresthesias in the upper and lower extremities and progressive gait instability, which had eventually limited him to a wheelchair. The complete blood count was normal, the lactate dehydrogenase (LDH) level was elevated at 303 $\mathrm{U} / 1$. Examination was remarkable for a $2-\mathrm{cm}$ right supraclavicular node, mild weakness and decreased grip strength in his right upper extremity, prominent muscular fasciculations, significant atrophy and hyporeflexia throughout his lower extremities.

A combined positron emission tomography/computed tomography (PET/CT) and a bone marrow biopsy revealed limited stage (IIA) disease with a revised International Prognostic Index (R-IPI) of 2. He was treated with 4 cycles of cyclophosphamide, doxorubicin, vincristine and prednisone (CHOP), with the addition of the monoclonal anti-CD20 antibody rituximab, followed by involved field radiation therapy. Due to concern for exacerbation of the patient's pre-existing neurologic symptoms, vincristine was dose-reduced to $0.35 \mathrm{mg} / \mathrm{m}^{2}$ for cycle 1 and to $0.7 \mathrm{mg} / \mathrm{m}^{2}$ for cycles $2-4$. The patient reported

\section{KARGER}

Fax +4161306 1234 E-Mail karger@karger.ch www.karger.com
(C) 2012 S. Karger AG, Basel

0030-2414/12/0823-0165\$38.00/0

Accessible online at:

www.karger.com/ocl
Ephraim Hochberg, MD

Massachusetts General Hospital Cancer Center

Yawkey Building, 55 Fruit Street

Boston, MA 02114 (USA)

Tel. +1 617724 4000, E-Mail ehochberg@ partners.org 
Table 1. Vinca alkaloid administration in patients with hereditary neuropathies: patient characteristics, therapies and outcome

\begin{tabular}{|c|c|c|c|c|c|c|c|c|c|}
\hline Reference & Diagnosis & $\begin{array}{l}\text { Oncologic } \\
\text { diagnosis }\end{array}$ & $\begin{array}{l}\text { Age } \\
\text { years }\end{array}$ & $\begin{array}{l}\text { Gen- } \\
\text { der }\end{array}$ & $\begin{array}{l}\text { Chemo- } \\
\text { therapy }\end{array}$ & $\begin{array}{l}\text { Dose of } \\
\text { vincristine } \\
\mathrm{mg}\end{array}$ & Symptoms after VCR & $\begin{array}{l}\text { Later VCR } \\
\text { treatment }\end{array}$ & $\begin{array}{l}\text { Neurological } \\
\text { outcome }\end{array}$ \\
\hline $\begin{array}{l}\text { Weiden and } \\
\text { Wright [11], } \\
1972\end{array}$ & CMT & $\begin{array}{l}\text { embryonal } \\
\text { cell carcinoma } \\
\text { of the testis }\end{array}$ & 46 & M & VCR, B & 4 & $\begin{array}{l}\text { severe weakness rapidly progressed to } \\
\text { paraplegia, respiratory failure }\end{array}$ & withheld VCR & death \\
\hline $\begin{array}{l}\text { Griffiths } \\
\text { et al. [12], } 1985\end{array}$ & CMT & NHL & 57 & $\mathrm{~F}$ & $\begin{array}{l}\text { VCR, } \\
\text { CTX, P }\end{array}$ & 2 & severe weakness & withheld VCR & improved \\
\hline $\begin{array}{l}\text { Graf } \\
\text { et al. [13], } 1996\end{array}$ & $\begin{array}{l}\text { CMT } \\
\text { type } 1 \mathrm{~A}\end{array}$ & NHL & 18 & $\mathrm{~F}$ & $\begin{array}{l}\text { modified } \\
\text { CHOP with } \\
\text { IT MTX/ } \\
\text { HDMTX }\end{array}$ & 2 & $\begin{array}{l}\text { severe weakness, feet anesthesia with } \\
\text { finger dysesthesia, absence of light touch, } \\
\text { vibration and position sense, absence of } \\
\text { tendon reflexes, hand tremors, restless leg } \\
\text { movements }\end{array}$ & withheld VCR & $\begin{array}{l}\text { regained } \\
\text { ambulation } \\
\text { at } 1 \text { year }\end{array}$ \\
\hline $\begin{array}{l}\text { Graf } \\
\text { et al. [13], } 1996\end{array}$ & $\begin{array}{l}\text { CMT } \\
\text { type } 1 \mathrm{~A}\end{array}$ & $\begin{array}{l}\text { embryonal } \\
\text { cell carcinoma } \\
\text { of the testis }\end{array}$ & 46 & M & VCR & 2 & $\begin{array}{l}\text { quadriplegia, involvement of the bulbar } \\
\text { musculature, pneumonia, respiratory } \\
\text { failure }\end{array}$ & $\begin{array}{l}\text { not } \\
\text { reported }\end{array}$ & death \\
\hline $\begin{array}{l}\text { Hildebrandt } \\
\text { et al. [14], } 2000\end{array}$ & $\begin{array}{l}\text { CMT } \\
\text { type } 1 \mathrm{~A}\end{array}$ & NHL & 52 & F & $\mathrm{CHOP}$ & 4 & $\begin{array}{l}\text { severe weakness, paresthesia of the } \\
\text { fingertips, bilateral sensory impairment } \\
\text { of feet and lower legs and slight dysphagia }\end{array}$ & withheld VCR & $\begin{array}{l}\text { improving at } \\
6 \text { months }\end{array}$ \\
\hline $\begin{array}{l}\text { Naumann } \\
\text { et al, [15], } 2001\end{array}$ & $\begin{array}{l}\text { CMT } \\
\text { type } 1 \mathrm{~A}\end{array}$ & HL & 31 & F & BEACOPP & 2 & severe weakness & withheld VCR & $\begin{array}{l}\text { improving at } \\
6 \text { months }\end{array}$ \\
\hline $\begin{array}{l}\text { Kalfakis } \\
\text { et al. [10], } 2002\end{array}$ & HNPP & NHL & 37 & $\mathrm{~F}$ & $\mathrm{CHOP}$ & 4 & $\begin{array}{l}\text { severe weakness leading to tetraparesis, } \\
\text { absence of tendon reflex }\end{array}$ & withheld VCR & $\begin{array}{l}\text { improving at } \\
4 \text { months }\end{array}$ \\
\hline $\begin{array}{l}\text { Cil } \\
\text { et al. [16], } 2009\end{array}$ & $\begin{array}{l}\text { CMT } \\
\text { type } 1 \mathrm{~A}\end{array}$ & $\mathrm{HL}$ & 17 & $\mathrm{~F}$ & $\begin{array}{l}\text { ABVD } \\
\text { (VCR) }\end{array}$ & 2 & $\begin{array}{l}\text { severe weakness, hypoesthesia, absence } \\
\text { of deep tendon reflexes }\end{array}$ & $\begin{array}{l}\text { withheld VCR, } \\
\text { gabapentin }\end{array}$ & $\begin{array}{l}\text { improving at } \\
12 \text { months }\end{array}$ \\
\hline
\end{tabular}

VCR = Vincristine; CMT = Charcot-Marie-Tooth disease; $\mathrm{B}=$ Bleomycin; NHL = non-Hodgkin lymphoma; CTX = cyclophosphamide; $\mathrm{P}=$ prednisone; IT = intrathecal; MTX = methotrexate; HDMTX = high dose methotrexate; $\mathrm{CHOP}=$ cyclophosphamide, doxorubicin, vincristine, prednisone; $\mathrm{HL}=$ Hodgkin lymphoma; BEACOPP = bleomycin, etoposide, doxorubicin, cyclophosphamide, vincristine, procarbazine, prednisone; HNPP = hereditary neuropathy with liability to pressure palsies; ABVD (VCR) = doxorubicin, bleomycin, vincristine, dacarbazine.

temporary exacerbation of his sensory paresthesias never worsening beyond common toxicity criteria grade 1 in the week following each chemotherapy cycle with prompt resolution. He reported no cumulative changes in his neurological status following 4 cycles of chemotherapy, and his neurological exam was stable. A complete response by PET criteria was achieved after 4 cycles of chemotherapy.

$\mathrm{MJD}$, also known as spinocerebellar ataxia type 3, is the most common of the autosomal dominant spinocerebellar ataxias [1]. MJD is caused by expanded CAG trinucleotide repeats in the ATXN3 locus in chromosome $14 \mathrm{q} 32.1$, resulting in the expression of polyglutamine tracts in the deubiquitinating ataxin 3 enzyme [1]. Trinucleotide repeat length is inversely correlated with the age of onset of symptoms, most commonly in the second to fifth decade, and is the most important prognostic factor in predicting the severity of the disease. The clinical findings are extremely heterogeneous and include gait ataxia, cerebellar dysarthria, dysphagia, clumsiness, oculomotor disturbances such as diplopia and nystagmus. Extrapyramidal signs comprise dystonic movements, chorea and parkinsonian features. Later, evidence of progressive symptomatic peripheral polyneuropathy with impairment in sensory nerve action potentials can occur [2]. Late in the disease course, patients are confined to a wheelchair, and later become bedridden. Currently, only symptomatic therapies are available.

Diffuse large B-cell lymphoma is the most common non-Hodgkin lymphoma in adults, comprising approximately $30 \%$ of all lymphomas and $90 \%$ of aggressive lymphomas [3]. Treatment options differ between patients with limited stage (Ann Arbor stage I-II) or advanced stage (Ann Arbor stage III-IV) disease. The presence of risk factors (namely high $\mathrm{LDH}$, advanced stage, age $>60$ years, more than one extranodal site, ECOG performance 
status $\geq 2$ ) in the IPI or, more recently, the R-IPI [4] is widely used as predictor of outcome.

$\mathrm{R}-\mathrm{CHOP}$ is the standard polychemotherapy regimen throughout the world $[5,6]$. Among the various toxic effects related to chemotherapy, vincristine-related peripheral and autonomic neuropathy is a common, doselimiting complication. Vinca alkaloids act by binding to intracellular tubulin, inducing alterations in the microtubuli structure leading to axonal edema. Early symptoms and signs of neuropathy are paresthesia and hyperesthesia of the extremities, with disappearance of deep tendon reflexes. Continued exposure the vincristine results in muscle cramps and myopathy. More rarely, signs of autonomic nervous system dysfunction such as orthostatic hypotension, constipation, urinary bladder dysfunction and erectile impotence may occur, and disturbances of eye movements and paralysis of the vocal cords have been reported [7]. Toxicity is related to dosage, frequency of administration and patient age and is usually slowly reversible upon removal of the drug. Fulminant neuropathy with severe motor involvement that can lead to tetraplegia, often misdiagnosed as acute Guillain-Barré syndrome, has been reported in pediatric and adult patients with underlying Charcot-Marie-Tooth disease, a group of inherited disorders featuring peripheral neuropathy [8]. A small study suggested that Charcot-MarieTooth disease should be considered as an underlying condition in pediatric cancer patients who have severe vincristine-induced peripheral neurotoxicity [9]. A case of severe neurotoxicity following vincristine administration has been described in a patient with hereditary neuropathy with liability to pressure palsies, an inherited recurrent focal demyelinating neuropathy, characterized by painless nerve palsies at common sites of compression and entrapment of peripheral nerves [10].

In contrast, tolerance to vincristine has been reported in a patient with Leber's hereditary optic neuropathy [11]. Table 1 provides a summary of adult patients with hereditary neuropathy treated with vinca alkaloid who developed severe neurotoxicity.

To our knowledge, this is the first report of a patient with MJD treated with a vinca alkaloid. The patient's tolerance of this microtubule toxin demonstrates a lack of synergy between these agents and the neuropathy attributable to MJD.

\section{References}

1 Rüb U, Brunt ER, Deller T: New insights into the pathoanatomy of spinocerebellar ataxia type 3 (Machado-Joseph disease). Curr Opin Neurol 2008;21:111-116.

-2 França MC, D’Abreu A, Nucci A, Cendes F, Lopes-Cendes I: Prospective study of peripheral neuropathy in Machado-Joseph disease. Muscle Nerve 2009;40:1012-1018.

-3 Armitage J, Weisenburger D: New approach to classifying non-Hodgkin's lymphomas: clinical features of the major histologic subtypes. Non-Hodgkin's Lymphoma Classification Project. J Clin Oncol 1998;16:27802795.

-4 Sehn LH, Berry B, Chhanabhai M, Fitzgerald C, Gill K, Hoskins P, Klasa R, Savage KJ, Shenkier T, Sutherland J, Gascoyne RD, Connors JM: The revised International Prognostic Index (R-IPI) is a better predictor of outcome than the standard IPI for patients with diffuse large B-cell lymphoma treated with R-CHOP. Blood 2007;109:1857-1861

5 Fisher RI, Miller TP, O’Connor OA: Diffuse aggressive lymphoma. Hematology Am Soc Hematol Educ Program 2004;221-236.
6 Sehn LH, Donaldson J, Chhanabhai M, Fitzgerald C, Gill K, Klasa R, MacPherson N, O’Reilly S, Spinelli JJ, Sutherland J, Wilson KS, Gascoyne RD, Connors JM: Introduction of combined CHOP plus rituximab therapy dramatically improved outcome of diffuse large B-cell lymphoma in British Columbia. J Clin Oncol 2005;23:50275033.

7 Quasthoff S, Hartung HP: Chemotherapyinduced peripheral neuropathy. J Neurol 2002;249:9-17.

-8 Trobaugh-Lotrario AD, Smith AA, Odom LF: Vincristine neurotoxicity in the presence of hereditary neuropathy. Med Pediatr Oncol 2003;40:39-43.

$\checkmark 9$ Chauvenet AR, Shashi V, Selsky C, Morgan E, Kurtzberg J, Bell B: Vincristine-induced neuropathy as the initial presentation of Charcot-Marie-Tooth disease in acute lymphoblastic leukemia: a Pediatric Oncology Group Study. J Pediatr Hematol Oncol 2003; 25:316-320.

10 Kalfakis N, Panas M, Karadima G, Floroskufi P, Kokolakis N, Vassilopoulos D: Hereditary neuropathy with liability to pressure palsies emerging during vincristine treatment. Neurology 2002;59:1470-1471.
Weiden PL, Wright SE: Vincristine neurotoxicity. N Engl J Med 1972;286:1369-1370.

12 Griffiths JD, Stark RJ, Ding JC, Cooper IA: Vincristine neurotoxicity in Charcot-MarieTooth syndrome. Med J Aust 1985; 143:305306.

13 Graf W, Chance P, Lensch M, Eng L, Lipe H, Bird T: Severe vincristine neuropathy in Charcot-Marie-Tooth disease type 1A. Cancer 1996;77: 1356-1362.

14 Hildebrandt G, Holler E, Woenkhaus M, Quarch G, Reichle A, Schalke B, Andreesen $\mathrm{R}$ : Acute deterioration of Charcot-MarieTooth disease IA (CMTIA) following $2 \mathrm{mg}$ of vincristine chemotherapy. Ann Oncol 2000; 11:743-747.

15 Naumann R, Mohm J, Reuner U, Kroschinsky F, Rautenstrauss B, Ehninger G: Early recognition of hereditary motor and sensory neuropathy type 1 can avoid life-threatening vincristine neurotoxicity. $\mathrm{Br} \mathrm{J}$ Haematol 2001; 115:323-325

16 Cil T, Altintas A, Tamam Y, Battaloglu E, Isikdogan A: Low dose vincristine-induced severe polyneuropathy in a Hodgkin lymphoma patient: a case report (vincristine-induced severe polyneuropathy). J Pediatr $\mathrm{He}$ matol Oncol 2009;31:787-789. 